NOAA

Abstract-Hogfish (Labridae: Lachnolaimus maximus) is distributed across several biogeographic regions, but its stock structure has been poorly documented, confounding stock assessment and management of this reef fishery species. In this study the genetic structure of hogfish over a portion of its southeastern U.S. range was examined by using a suite of 24 microsatellite DNA loci. Fin clips from 719 specimens were obtained from geographic locations ranging from northwest Florida through North Carolina. Genomic proportions of hogfish were partitioned into 3 distinct genetic clusters, geographically delineated as 1) the eastern Gulf of Mexico, 2) the Florida Keys and the southeast coast of Florida, and 3) the Carolinas. Clusters 1 and 2 converged along the coastal area west of the Florida Everglades, but the location of the genetic break between clusters 2 and 3 requires further study because of a discontinuity in specimen collection between southeast Florida and the Carolinas. The geographically limited reproductive exchange in this species indicates that future stock assessments should incorporate regionally partitioned analyses of life history and fishery data.

Manuscript submitted 6 May 2014 Manuscript accepted 13 August 2015. Fish. Bull 113:442-455 (2015).

Online publication date: 2 September 2015. doi: 10.7755/FB.113.7

The views and opinions expressed or implied in this article are those of the author (or authors) and do not necessarily reflect the position of the National Marine Fisheries Service, NOAA.

\title{
Genetically determined population structure of hogfish (Labridae: Lachnolaimus maximus) in the southeastern United States
}

\author{
Seifu Seyoum ${ }^{1}$ \\ Angela B. Collins ${ }^{1,3}$ (contact author) \\ Cecilia Puchulutegui ${ }^{1}$ \\ Richard S. McBride 2 \\ Michael D. Tringali ${ }^{1}$ \\ E-mail for contact author: angela.collins@myfwc.com \\ ${ }^{1}$ Fish and Wildlife Research Institute \\ Florida Fish and Wildlife Conservation Commission \\ 100 Eighth Avenue SE \\ St. Petersburg, Florida 33701 \\ 2 Population Biology Branch \\ Fisheries and Ecosystems Monitoring Division \\ Northeast Fisheries Science Center \\ National Marine Fisheries Service, NOAA \\ 166 Water Street \\ Woods Hole, Massachusetts 02543 \\ 3 Florida Sea Grant \\ University of Florida \\ Institute of Food and Agricultural Sciences Extension \\ $130317^{\text {th }}$ Street West \\ Palmetto, Florida 34221
}

A fundamental challenge for managing sustainable fisheries involves aligning biological evidence of stock structure with fishing and management sectors for the purpose of monitoring, assessment, and regulatory actions (Cadrin et al., 2014). This process is particularly challenging around the Florida peninsula, where several biogeographic regions overlap state and federal boundaries and fall under the jurisdiction of 2 federal fishery management councils (South Atlantic and Gulf of Mexico). In terms of biogeography, there is a strong environmental gradient both along (north-south) and between (east-west) coasts, resulting in distinctive faunal breaks at Cape Romano on the west coast of Florida and Cape Canaveral on the east coast (Briggs and Bowen, 2012). Subspecies are frequently recognized between the Gulf and Atlantic coasts of Florida (Bowen and Avise, 1990), and several coastal and marine species are considered to have distinct stocks on each coast (Tringali and Bert, 1996; Gold et al., 2002; McBride, 2014a).

Stock structure remains unclear for many marine fishery species, in part because of a lack of data (Cadrin et al., 2014; McBride, 2014a). One such example is the hogfish (Labridae: Lachnolaimus maximus), a longlived reef fish that occurs in temperate to tropical waters of the western Atlantic Ocean (from Brazil to Bermuda) and throughout the Gulf of Mexico (Claro et al., 1989; McBride and Richardson, 2007; McBride et 
al., 2008). This species supports a modest commercial fishery in the southeastern United States and is a highly valued target for recreational divers and spear fishermen (McBride and Murphy, 2003; $\mathrm{FWC}^{1}$; $\mathrm{NMFS}^{2}$ ). Hogfish occur in rocky and reef habitats, but those habitats are not continuous, and there are no studies that completely describe the continuity of their distribution along the Atlantic coast of the United States, let alone throughout their geographic range.

The available data pertinent to stock structure of hogfish are limited to general behavioral and life history patterns (e.g., Davis, 1976; McBride and Richardson, 2007; Collins and McBride, 2011) and to a preliminary genetic survey of this species in the eastern Gulf of Mexico (MERPDC, 2012). Hogfish are broadcast spawners, a characteristic that facilitates dispersal of the propagules away from the spawning site (Colin, 1982). The planktonic larval duration is $3-5$ weeks (Colin, 1982; Victor, 1986), which is an average period among reef fishes (Victor, 1986; Leis et al., 2013) and does not imply extensive mixing of genotypes between ocean basins. Moreover, hogfish maintain site fidelity and spawn in stable, site-specific harems (i.e., they do not migrate long distances to form spawning aggregations; Colin, 1982; Muñoz et al., 2010), and there is evidence of reciprocal onshore larval dispersal and gradual offshore movement with growth (Collins and McBride, 2011). These behaviors have the potential to promote stock structure at a finer spatial scale than might be expected in an open marine ecosystem.

Life history differences (e.g., maximum age, maximum size, and fecundity) have been noted for hogfish in the eastern Gulf of Mexico and hogfish in south Florida (McBride et al., 2008), and variations also exist among fish within the same region (McBride and Richardson, 2007; Collins and McBride, 2011, 2015). Hogfish grow older and larger, and spawn more eggs per female, in areas with lower fishing rates or in less gear-accessible habitats. Although these patterns affect vital rates within each region, they have not been linked to underlying biological stock structure (Collins and McBride 2011; McBride and Richardson, 2007; McBride et al., 2008; MERPDC, 2012; McBride, 2014b). Questions regarding the underlying stock structure were raised most recently in a request to review hogfish stock structure and unit stock definitions as part of the most recent southeastern U.S. hogfish benchmark assessment (Cooper et al. ${ }^{3}$ ).

The goal of this research was to use genetic data to determine whether more than one stock of hogfish ex-

\footnotetext{
${ }^{1}$ FWC (Florida Fish and Wildlife Conservation Commission). 2013. Species account: Hogfish (Lachnolaimus maximus) in Florida, 4 p. [Available at website.]

2 NMFS [National Marine Fisheries Service]. 2013. Commercial fisheries statistics. [Available at website.]

${ }^{3}$ Cooper, W., A. Collins, J. O'Hop, and D. Addis. 2014. The 2013 stock assessment report for hogfish in the South Atlantic and Gulf of Mexico, 569 p. Fish Wildl. Res. Inst., Florida Fish Wildl. Conserv. Comm., St. Petersburg, FL. [Available at website.]
}

ists in the southeastern United States and, if so, where the genetic breaks occur. We used microsatellite DNA markers, which are preferred over other types of markers (e.g., allozymes and mitochondrial DNA) because of their ability to better detect the subtle genomic differences common among marine populations (Antoniou and Magoulas, 2014; Mariani and Bekkevold, 2014). Microsatellites are nuclear-encoded, codominant markers that have characteristically high mutation rates and, hence, a high degree of allelic variation. These loci are scattered throughout the genome and can be influenced independently by recombination, selection, and drift; therefore, each locus is expected to have its own genealogical history that is slightly different from that of others. Adding and combining many loci makes a genomic sampling increasingly representative of the history of the previously described genetic processes and provides a robust method for investigating gene flow and population connectivity (Hedrick, 1999; Kalinowski, 2002, 2005; Wilson and Rannala, 2003). Here we apply microsatellite loci previously isolated for hogfish and optimized for routine assay (MERPDC, 2012) to specimens collected in an area from the Big Bend region of northwest Florida through North Carolina.

\section{Materials and methods}

\section{Specimen collection and DNA extraction}

Specimens $(\mathrm{N}=719)$ were collected through intercepts of recreational and commercial spear fishermen or during directed research trips performed by biologists of the Fish and Wildlife Research Institute of the Florida Fish and Wildlife Conservation Commission. Specimens were identified according to Robins and Ray (1986) and were collected sporadically throughout the study area from November 2005 through August 2013. Fin clips were removed and preserved in $70 \%$ ethanol. Total DNA was isolated from approximately $500 \mathrm{mg}$ of fin clip tissue with Gentra Puregene ${ }^{4}$ DNA isolation kits (Qiagen, Valencia, CA) and rehydrated in $50 \mu \mathrm{L}$ of deionized water.

Collection locations were subdivided into 9 geographic areas, referred to hereafter as sampling areas 1-9 (Fig. 1). These sampling areas were identified predominantly by latitude and coast (west [Gulf of Mexico] and east [Atlantic Ocean]) to delineate geographic regions corresponding to recognized faunal breaks, major estuaries, and (on a broader scale) management jurisdictions of hogfish. For example, faunal breaks are known to occur at Cape Romano (between sampling areas 5 and 6), at Cape Sable (between sampling areas 6 and 7), and at Cape Canaveral (between sampling areas 8 and 9) (Briggs and Bowen, 2012). Considerable estuarine flow onto the continental shelf occurs from

\footnotetext{
${ }^{4}$ Mention of trade names of commercial companies is for identification purposes only and does not imply endorsement by the National Marine Fisheries Service, NOAA.
} 


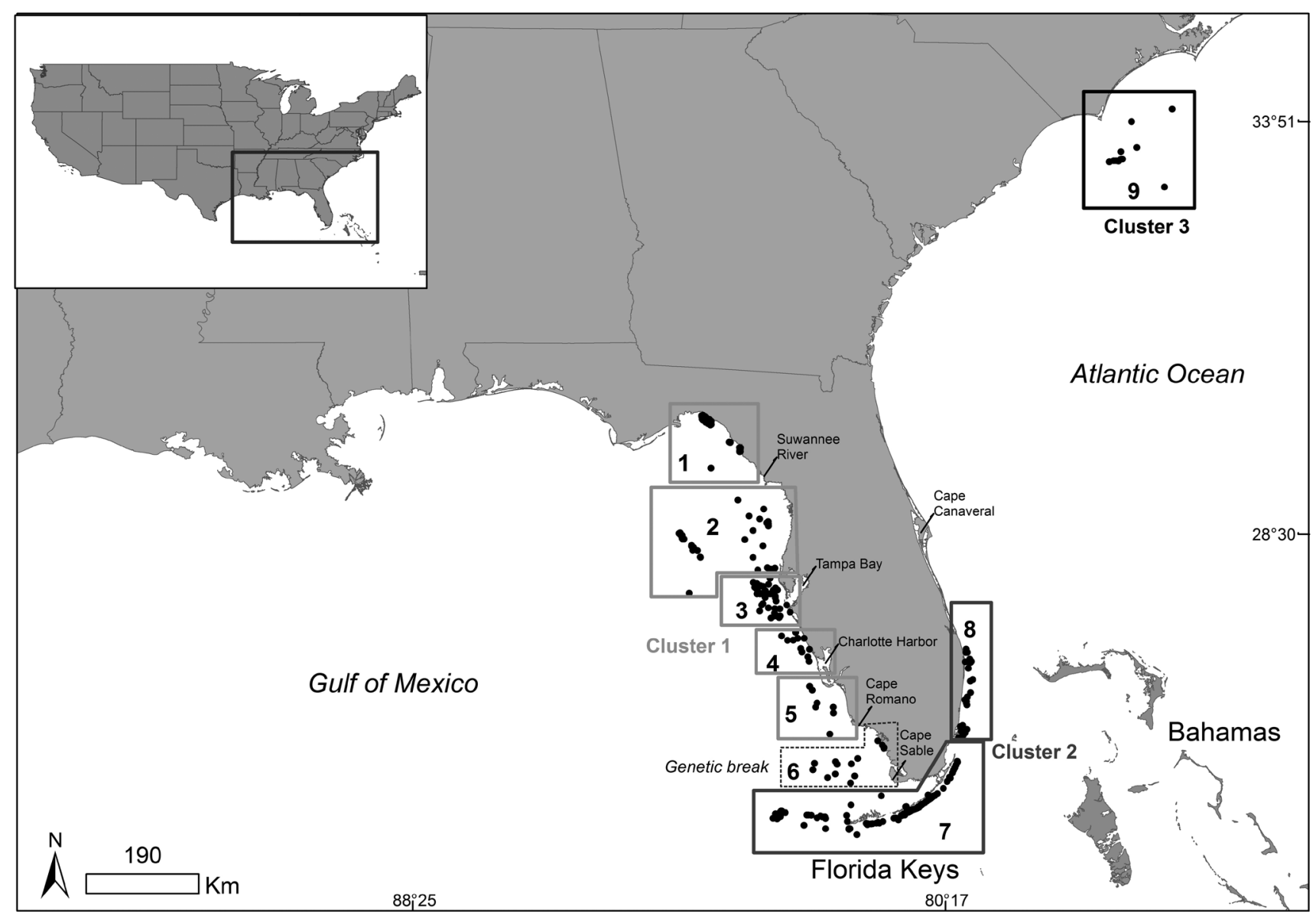

Figure 1

Capture locations for the specimens of hogfish (Lachnolaimus maximus) that were used to genetically determine the population structure within the southeastern United States. Specimens were collected sporadically between November 2005 and August 2013 and were grouped by collection location into sampling areas 1-9, where 1=Big Bend, 2=Nature Coast and Florida Middle Grounds, 3=Tampa Bay, 4=Sarasota, 5=Naples, 6=Everglades, 7=Florida Keys, 8=East Florida, 9=Carolinas. Three distinct clusters were identified as the 1) eastern Gulf of Mexico; 2) Florida Keys and southeast Florida; and 3) Carolinas, on the basis of the genetically determined population structure detected with 24 microsatellite loci. Sampling area 6 was identified as the region of gene flow restriction (genetic break) between clusters 1 and 2 .

the Suwannee River (between sampling areas 1 and 2), Tampa Bay (in sampling area 3), and Charlotte Harbor (in sampling area 4). In terms of management jurisdictions, the Gulf of Mexico Fishery Management Council regulates federal waters throughout the Gulf of Mexico (which includes sampling areas 1-6), and the South Atlantic Fishery Management Council regulates federal waters from the Florida Keys through the Carolinas (an area that includes sampling areas 7-9). The state of Florida regulates state waters within $14.5 \mathrm{~km}(9 \mathrm{mi})$ from shore in the Gulf of Mexico and $4.9 \mathrm{~km}$ (3 mi) from shore in the Atlantic Ocean.

\section{Microsatellite genotyping}

Specimens were genotyped by using 24 of the 29 microsatellite markers identified in MERPDC (2012); markers Lmax11, Lmax14, Lmax15, Lmax24, and Lmax31 were not used. Multiplex polymerase chain reaction amplifications were carried out in a Mastercycler Pro thermal cycler (Eppendorf North America, Hauppauge, $\mathrm{NY}$ ) containing $50-100 \mathrm{ng}$ of total DNA, $10 \mu \mathrm{L}$ of 50 $\mu \mathrm{M}$ dNTP mix, $0.25 \mu \mathrm{L}$ of $0.1 \mathrm{mg} / \mathrm{mL}$ bovine serum albumin, a combination of 3 optimally selected primers of 3 loci with each forward primer labeled with a different fluorescent dye, $5 \mathrm{\mu L}$ of Taq polymerase $10 \times$ buffer (Promega, Madison, WI) containing $15 \mathrm{mM} \mathrm{MgCl}_{2}$ and 1.25 units of Taq polymerase (Promega). The reaction profile was $94^{\circ} \mathrm{C}$ for $2 \mathrm{~min}, 35$ cycles of $94^{\circ} \mathrm{C}$ for $35 \mathrm{~s}, 55^{\circ} \mathrm{C}$ for $35 \mathrm{~s}, 72^{\circ} \mathrm{C}$ for $35 \mathrm{~s}$, and final extension at $72^{\circ} \mathrm{C}$ for $30 \mathrm{~min}$. Fragments were visualized on an Applied Biosystems 3130 XL genetic analyzer (Thermo Scientific Inc., Waltham, MA) and genotyped with GeneMapper software, vers. 4.0 (Thermo Scientific Inc.). For fragment assays, we used GeneScan 500 ROX Size Standard (Thermo Scientific Inc.). 


\section{Data analysis}

Standard genetic measures and distances Data files for use in GENEPOP, vers. 4.3 (Rousset, 2008) were generated from fragment sizes recorded with the Microsatellite Toolkit add-on, vers. 3.1.1 (Park, 2001; available at website) for Microsoft Excel (Microsoft Corp., Redmond, WA); this GENEPOP data file was converted to other formats as needed with the conversion tool PGDspider, vers. 2.0.1.9 (Lischer and Excoffier, 2012). Pairwise genetic distances $\left(F_{\mathrm{ST}}\right)$ between sampling areas (Weir and Cockerham, 1984) were estimated with 10,000 permutations with the software program GENETIX (Belkhir et al., 2000). Departures from HardyWeinberg equilibrium were determined with GENEPOP. Sequential Bonferroni corrections were applied to multiple tests of hypotheses (Rice, 1989). Observed $\left(H_{0}\right)$ and expected heterozygosity $\left(H_{\mathrm{e}}\right.$, with and without a bias correction), averaged over all loci, were obtained from GENETIX (Belkhir et al., 2000). Null allelism was investigated by using the randomization test of Guo and Thompson (1992) and the $U$-test statistic of Raymond and Rousset (1995), with the software program ML-NullFreq (available at website). For each locus, microsatellite variation was quantified in terms of genetic diversity, number of alleles, and allelic richness-a diversity measure that corrects for differences in sample size, with the program FSTAT, vers. 2.9.3.2 (Goudet, 2001). Chi-square tests were performed to determine whether sampling areas differed significantly from the previously described standard genetic measures.

Genetic structure Genetic data from specimens collected from the 9 sampling areas were examined with 3 analytical approaches. The first was based on principal coordinate analysis (PCA) to discriminate genetic clusters within the data by using the program GenAlEx, vers. 6.5 (Peakall and Smouse, 2006, 2012). The data were plotted at the first 2 primary coordinates on the basis of pairwise $F_{\text {ST }}$ values for sampling areas (Latter, 1972) computed without sample size bias correction (uncorrected $F_{\mathrm{ST}} ; \mathrm{Nei}, 1973$ ) and with sample size bias correction (corrected $F_{\mathrm{ST}}$; Nei and Roychoudhury, 1974; Nei, 1987) with the software POPTREE2 (Takezaki et al., 2010).

The second method of examining the genetic structure was based on analysis of molecular variance (AMOVA) as implemented in the software program ARLEQUIN, vers. 3.5.1.3; 100,000 permutations (Excoffier and Lischer, 2010). Essentially a method to determine the strength of the PCA groupings, AMOVA assesses the best grouping of sampling areas into clusters. In the a priori hierarchical approach with AMOVA, correlations among genotypes at various levels are partitioned as $F$-statistics. Initially, the a priori hierarchical structure that was analyzed was based on the genetic groupings revealed by PCA. To find the greatest $F_{\text {ST }}$ between groupings, we constructed 2 combinations of 3 -clusters that placed sampling area 6 in either cluster 1 or cluster 2 on the basis of corrected or uncorrected
$F_{\text {ST }}$ values indicated by PCA. After this analysis, $F_{\mathrm{ST}}$ values for the 2 -cluster combinations were also assessed by omitting one cluster at a time. The proportions of variation were computed among clusters $\left(F_{\mathrm{CT}}\right)$, within clusters $\left(F_{\mathrm{SC}}\right)$, and within sampling areas $\left(F_{\mathrm{ST}}\right)$, and the $F$-statistic was assessed by the permutation method of Excoffier et al. (1992).

The third analytical approach was based on the Bayesian population-assignment algorithm as implemented in the program STRUCTURE, vers. 2.3.4 (Pritchard et al., 2000). With this algorithm, individuals were probabilistically and proportionally assigned to one or more genetic clusters $(K)$ in a manner that minimized Hardy-Weinberg and linkage disequilibria among their multilocus genotypes. For $K=1$ through $K=9$, 10 simulations were conducted by using 2 million Markov chain Monte Carlo replicates after a burn-in period of 1 million runs. We adopted the admixture model and the independent allele frequency option to minimize the chance of overestimating the number of clusters present in the data (Pritchard et al., 2009).

We used STRUCTURE HARVESTER, vers. 0.6.93 (Earl and vonHoldt, 2012) with each of the previously described replicate runs to compute the ad hoc statistics $\mathrm{L}(K)$ and $\Delta K$ so that we could determine the most plausible base value for $K$ clusters (i.e., the upper-level hierarchy). $\mathrm{L}(K)$ denotes the log probability of the data at a given modeled $K$ value; $\Delta K$ is based on the rate of change in $\mathrm{L}(K)$ between successively modeled $K$ values. Simulation studies (Evanno et al., 2005) have shown that $\Delta K$ provides the most accurate indication of genetic structure under a variety of modeling conditions. We then used CLUMPP, vers. 1.1.2 (Jakobsson and Rosenberg, 2007) to determine the optimal alignment for replicate analyses and mean genomic membership coefficients across replicate runs for sampling areas and individuals. The coefficients of the CLUMPP output were plotted with Microsoft Excel.

Mantel test To determine whether genetic relationships among sampling areas conformed to a pattern of genetic isolation by distance (Wright, 1943; Malécot, 1955), we computed the Mantel correlation coefficient $(r)$ between $F_{\mathrm{ST}}$ and geographic distance (measured in kilometers) with the program GenAlEx, vers. 6.5 (Peakall and Smouse, 2006, 2012). The significance of $r$ was tested by using 9000 random permutations.

Effective population size The effective population size $\left(N_{\mathrm{e}}\right)$ of each cluster was estimated with the program NeEstimator, vers. 2 (Do et al., 2013) under the model option with the Burrows method to estimate linkage disequilibrium (Hill, 1981; Waples, 2006). This approach has been shown to give generally unbiased estimates of linkage disequilibrium from which estimates of $N_{\mathrm{e}}$ can be derived (Robinson and Moyer, 2012) with $95 \%$ confidence intervals on the basis of the parametric procedure of Waples (2006). Bias due to low-frequency alleles was avoided by estimating $N_{\mathrm{e}}$ from alleles with frequencies greater than $1 \%$ and $2 \%$ and also by omit- 
Table 1

Total number of hogfish (Lachnolaimus maximus) collected, time span of specimen collection, total number of alleles sampled, and standard genetic indices for each sampling area in the southeastern United States (from northwest Florida to North Carolina). Sampling areas 1-9 are geographically defined in Figure 1. Genetic measurements were calculated over a suite of 24 microsatellite loci, and mean values of genetic diversity, number of alleles per locus, allelic richness, and observed and unbiased observed heterozygosity are presented for each sampling area as well as for all specimens combined. Numbers in parentheses in the last column indicate overall mean values for all specimens combined.

\begin{tabular}{|c|c|c|c|c|c|c|c|c|c|c|}
\hline Sampling area & 1 & 2 & 3 & 4 & 5 & 6 & 7 & 8 & 9 & Total \\
\hline $\begin{array}{l}\text { Number of } \\
\text { specimens }\end{array}$ & 119 & 71 & 88 & 24 & 22 & 70 & 191 & 32 & 102 & 719 \\
\hline $\begin{array}{l}\text { Time span of } \\
\text { specimen collection } \\
\text { (years) }\end{array}$ & $\begin{array}{c}2007- \\
2012\end{array}$ & $\begin{array}{c}2005- \\
2012\end{array}$ & $\begin{array}{c}2005- \\
2012\end{array}$ & $\begin{array}{c}2006- \\
2012\end{array}$ & $\begin{array}{c}2006- \\
2012\end{array}$ & $\begin{array}{c}2006- \\
2012\end{array}$ & $\begin{array}{c}2009- \\
2013\end{array}$ & $\begin{array}{c}2009- \\
2013\end{array}$ & $\begin{array}{c}2010- \\
2012\end{array}$ & $\begin{array}{c}2005- \\
2013\end{array}$ \\
\hline $\begin{array}{l}\text { Total number } \\
\text { of alleles }\end{array}$ & 246 & 223 & 237 & 165 & 161 & 238 & 296 & 203 & 174 & $\begin{array}{c}350 \\
(216)\end{array}$ \\
\hline Genetic diversity & 0.63 & 0.65 & 0.65 & 0.63 & 0.64 & 0.67 & 0.67 & 0.68 & 0.61 & $\begin{array}{c}0.65 \\
(0.65)\end{array}$ \\
\hline $\begin{array}{l}\text { Number of alleles } \\
\text { per locus }\end{array}$ & 10.3 & 9.3 & 9.9 & 6.9 & 6.7 & 9.9 & 12.3 & 8.5 & 7.3 & $\begin{array}{l}14.6 \\
(9.0)\end{array}$ \\
\hline Allelic richness & 9.5 & 9.0 & 9.7 & 9.6 & 6.3 & 9.7 & 12.2 & 8.2 & 7.1 & $\begin{array}{l}14.4 \\
(9.0)\end{array}$ \\
\hline $\begin{array}{l}\text { Observed } \\
\text { heterozygosity }\end{array}$ & 0.57 & 0.59 & 0.60 & 0.61 & 0.59 & 0.63 & 0.63 & 0.63 & 0.58 & $\begin{array}{l}0.60 \\
(0.60)\end{array}$ \\
\hline $\begin{array}{l}\text { Unbiased observed } \\
\text { heterozygosity }\end{array}$ & 0.63 & 0.65 & 0.65 & 0.63 & 0.64 & 0.66 & 0.67 & 0.68 & 0.61 & $\begin{array}{c}0.66 \\
(0.65)\end{array}$ \\
\hline Expected heterozygosity & 0.63 & 0.64 & 0.64 & 0.62 & 0.63 & 0.66 & 0.66 & 0.67 & 0.60 & $\begin{array}{c}0.66 \\
(0.64)\end{array}$ \\
\hline
\end{tabular}

ting sampling area 6 , which was a mixture of cluster 1 and cluster 2 , to avoid interference with linkage disequilibrium.

\section{Results}

\section{Standard genetic measures and distances}

Significant heterozygote deficiencies were sporadically detected at 3 loci (Lmax4, Lmax29, and Lmax 35) in up to 5 sampling areas. Presumptive frequencies of null alleles at those loci that exhibited heterozygote deficits ranged from 0.17 to 0.24 . There were no significant differences among sampling areas in the mean values of standard genetic measures (Table 1). For all loci, 350 alleles were identified (mean=216) over all 9 sampling areas. Over the 36 possible pairwise comparisons, 30 sampling area pairs had $F_{\mathrm{ST}}$ values that were significantly greater than zero $(10,000$ permutations; $P<0.05)$.

\section{Principal coordinate analysis}

The PCA defined 3 genetic clusters, with the primary axis (coordinate 1) explaining $58.9 \%$ and the secondary axis (coordinate 2) explaining $38.9 \%$ of the genetic variability from the uncorrected $F_{\mathrm{ST}}$ values (Fig. $2 \mathrm{~A}$ ), compared with $68.0 \%$ and $32.0 \%$ on the basis of the corrected $F_{\text {ST }}$ values (Fig. $2 \mathrm{~B}$ ). Cluster 1 included specimens collected in the eastern Gulf of Mexico from the Florida Panhandle to Naples (sampling areas 1-5). Cluster 2 included specimens collected from the Florida Keys and along the southeastern coast of Florida (sampling areas 7 and 8). Cluster 3 included specimens collected from the Carolinas (sampling area 9). The cluster identity of sampling area 6 (Everglades region) was unresolved, falling between cluster 1 and cluster 2 when analyzed on the basis of uncorrected $F_{\mathrm{ST}}$ (Fig. 2A).

\section{Analysis of molecular variance}

The AMOVA revealed that $98.2 \%$ of the variation occurred within sampling areas and $1.8 \%$ occurred among sampling areas. The overall $F_{\mathrm{ST}}$ value of 0.018 $(P<0.001)$ indicated significant differentiation among sampling areas due to the presence of spatial structure at both regional and local scales. The greatest among-cluster variance in the AMOVA (Table 2) was observed when sampling areas were grouped according to the PCA results that were based on corrected $F_{\text {ST }}$ (Fig. 2B) - an approach that placed sampling area 6 into cluster 1 . Translocation of sampling area 6 from cluster 1 to cluster 2 only slightly reduced the amongcluster variance (Table 2 ). 
Pairwise $F_{\mathrm{CT}}$ values between uncorrected (and corrected) $F_{\mathrm{ST}}$ values were $0.015(0.016)$ between clusters 1 and 2, $0.027(0.023)$ between clusters 1 and 3 , and $0.030(0.039)$ between clusters 2 and 3 (Table 2). All pairwise $F_{\mathrm{CT}}$ comparisons among the clusters were highly significant $(P<0.001)$. Overall, the $F_{\mathrm{ST}}$ statistic and the AMOVA confirmed the presence of 3 geographically based clusters, but these clusters appeared to be hierarchically arranged; the least genetic differentiation was seen between clusters 1 and 2 and the differentiation between clusters 2 and 3 exceeded that observed between the geographically disjunctive clusters 1 and 3 . Interestingly, the observed pattern of genetic differentiation did not conform with the expected greatest differentiation between clusters separated by the greatest geographic distances.

\section{Bayesian population assignment}

Lacking a method for determining whether values of $\mathrm{L}(K)$ statistically differed, we derived inferences herein by evaluating replicate likelihoods and resultant $\Delta K$ statistics for different values of $K$. $\mathrm{L}(K)$ increased quickly from $K=1$ to $K=2$ and somewhat less quickly from $K=2$ to $K=3$, reaching a plateau at successive values $(\mathrm{L}(K)$; Fig. 3). The largest value of $\Delta K$ occurred for $K=2 \quad(\Delta K=281)$ and, secondarily, for $K=3 \quad(\Delta K=118)(\Delta K$; Fig. 3 ). At the base hierarchical level of $K=2$, sampling areas of clusters 1 and 3 were predominantly conjoined within a single Bayesian cluster, whereas sampling areas of cluster 2 were predominantly assigned to a discrete Bayesian cluster (Fig. 4A). Virtually the same result was obtained under the model of no admixture analysis for $K=2$. At the next hierarchical level of $K=3$, sampling areas of clusters 1 and 3 were assigned to different Bayesian clusters (Fig. 4B). The CLUMPP analysis indicated that sampling areas 5 and 6 , were admixtures of Bayesian clusters 1 and 2 , respectively, exhibiting graduated mean genomic proportions (Fig. 4C).

\section{Mantel test}

The number of paired comparisons within cluster 1 (from Big Bend to the Everglades) was sufficient to allow only a within-cluster Mantel test. No significant correlation was observed between genetic and geographic distances $(P=0.125, r=0.334)$. The $F_{\mathrm{ST}}$ value between sampling areas 7 and 8 was not significant $\left(F_{\mathrm{ST}}=\right.$ $-0.0007 P>0.9$ ). However, when sampling areas 7 and 8 were included in the Mantel test with the sampling

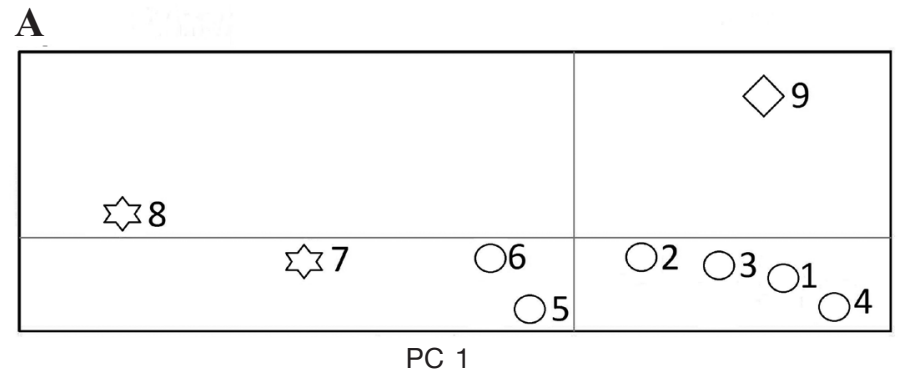

B

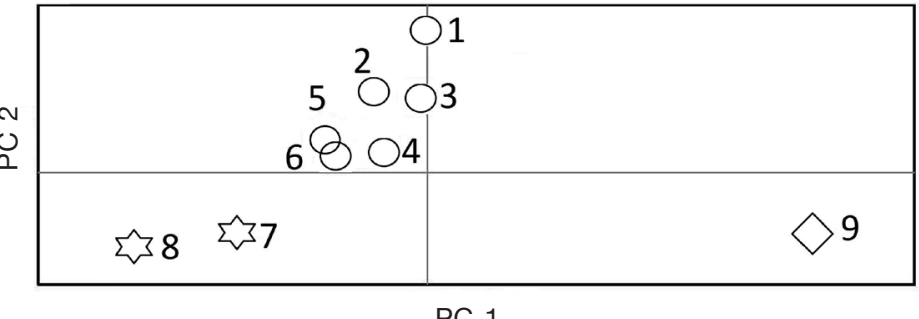

Cluster $1 \quad \diamond$ Cluster 3

Figure 2

Principal coordinate analysis based on a nonstandardized distance method of a matrix of pairwise (A) uncorrected and (B) corrected genetic distances $\left(F_{\mathrm{ST}}\right)$ between sampling areas 1-9 for specimens of hogfish (Lachnolaimus maximus) collected from November 2005 through August 2013 in the southeastern United States (from northwest Florida to the Carolinas). Analysis separated the 9 sampling areas into 3 main genetic clusters, with principal coordinate 1 (PC1) and PC2 explaining $58.9 \%$ and $38.8 \%$ of the variability for uncorrected and $68 \%$ and $32 \%$ of the variability for corrected, respectively. Sampling areas 1-9 are labeled numerically by geographic region as defined in Figure 1 and are identified as cluster 1 (circles), cluster 2 (stars), or cluster 3 (diamond). areas from cluster 1 , there was a significant correlation between genetic and geographic distance $(P=0.004$, $r=0.543$ ). This correlation was attributed to the genetic break between cluster 1 and cluster 2 rather than to isolation by distance.

\section{Effective population size}

The $1 \%$ allele-frequency criterion was used to determine the following estimates of $N_{\mathrm{e}}$ for each of the 3 clusters: cluster $1=1368.2$ (95\% confidence interval $[\mathrm{CI}]=1022.6-2033.4 ; n=324)$; cluster $2=1035.7$ (95\% CI $=833.5-1750.2 ; n=223)$; and cluster $3=285.6$ (95\% CI $=216.2-411.2 ; n=102)$. The $2 \%$ allele-frequency criterion yielded the following: cluster $1=1478.4(95 \% \mathrm{CI}=1022.6-2581.1)$; cluster $2=1075.5$ (95\% CI $=748.3-1853.8)$; and cluster $3=327.5(95 \%$ $\mathrm{CI}=231.9-537.23)$. The effective population size of cluster 3 (sampling area 9, from the Carolinas) was approximately 3 times smaller than that of the other 2 clusters. 


\section{Table 2}

Analysis of molecular variance (AMOVA) based on 24 microsatellite loci genotypes of hogfish (Lachnolaimus maximus) (number of specimens=719) collected from the southeastern United States (from northwest Florida to the Carolinas) between November 2005 and August 2013. Numbers joined by hyphens indicate sampling areas (as geographically defined in Fig. 1) combined into clusters and analyzed on the basis of either the corrected or uncorrected genetic distances $\left(F_{\mathrm{ST}}\right)$, which were indicated by principal coordinate analysis. Only the proportions of variation computed among clusters $\left(F_{\mathrm{CT}}\right)$ for 3 -cluster and 2 -cluster combinations are given here. Probability of finding a more extreme variance by chance alone (1000 permutations) was $<0.001$ for all computed FCT values.

Observed partition

AMOVA results

Among 3 clusters

Cluster 1

1-2-3-4-5-6

$1-2-3-4-5$

Cluster 2
$7-8$
$6-7-8$

Cluster 3
9
9

Cluster 3

Cluster 2

7-8

1-2-3-4-5-6

1-2-3-4-5-6

$-$

1-2-3-4-5

1-2-3-4-5

$-$
$-$

7-8

6-7-8

$-$

6-7-8
$-$

9

9

$-$

9

9

Variance
0.14768
0.14331

Total (\%)
2.07
2.02

Variance
0.11203
0.16073
0.28595
0.10629
0.17683
0.22038

Total (\%)
1.56
2.30
3.93
1.48
2.56
3.01

$F_{\mathrm{CT}}$
0.0156
0.0230
0.0393
0.0149
0.0256
0.0301

$F_{\mathrm{ST}}$
Corrected
Uncorrected

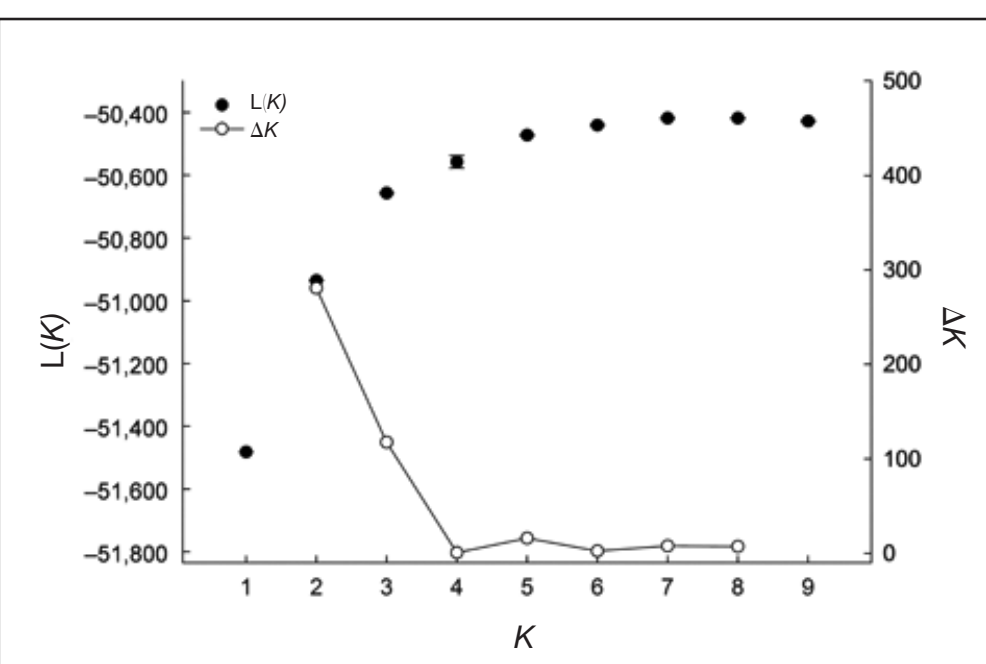

Figure 3

For $K=1$ through $K=9$, 10 simulations were conducted with 2 million Markov chain Monte Carlo replicates after a burn-in period of 1 million runs. $\mathrm{L}(K)$ denotes the log probability of the data at a given modeled $K$ value; $\Delta K$ is based on the rate of change in $\mathrm{L}(K)$ between successively modeled $K$ values. STRUCTURE HARVESTER was used to compute the ad hoc statistics $\mathrm{L}(K)$ and $\Delta K$ so that we could determine the most plausible base value of $K$ (number of genetic clusters) within the 9 sampling areas where specimens of hogfish (Lachnolaimus maximus) were collected from November 2005 through August 2013 from the southeastern United States (from northwest Florida to the Carolinas).

\section{Summary of genetic structure}

The PCA, AMOVA, and Bayesian population-assignment analyses elucidated a concordant pattern of genetic structure within the studied geographical range. Three geographically based clusters were delineated as 1) the eastern Gulf of Mexico, 2) the Florida Keys and southeastern Florida, and (3) the Carolinas (Fig. 1). There was no indication of genetic isolation by distance in the eastern Gulf or over the geographic range of specimens collected. The area west of the Florida Everglades (sampling area 6) appeared to serve as a genetic break between clusters 1 and 2 . The nature of the apparent genetic break between the Florida Keys and the Carolinas requires further study because of a discontinuity between sampling areas 8 and 9 .

\section{Discussion}

The results of this study indicate the existence of at least 3 genetically distinct hogfish stocks in the southeastern United States: the eastern Gulf of Mexico, south Florida and the Florida Keys, and the Carolinas. Specimens were collected over a rela- 


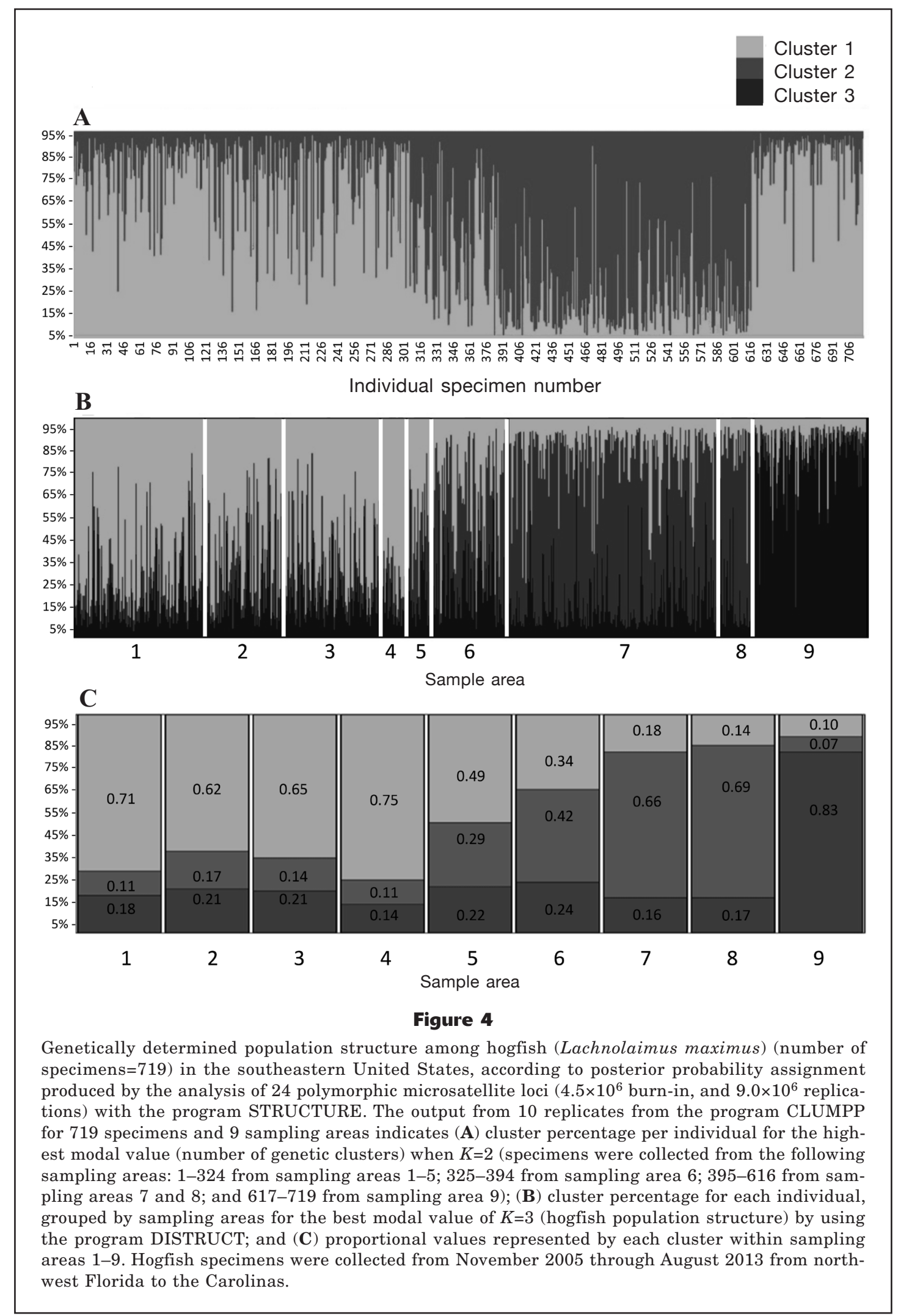


tively broad geographic distance and separated by the land mass of peninsular Florida; therefore, genetic differentiation across this scale was not necessarily surprising (Riginos et al., 2011). The factors that influence stock separation are not known but are explored here from 3 perspectives: in relation to other coastal and marine fishes; at a seascape level (particularly in regard to the descriptive hydrodynamics around Florida), and in terms of how these results affect stock assessment and management of this species.

In the western Atlantic Ocean, capes Romano and Canaveral have been identified previously as points of major shifts in marine animal community composition. Briggs and Bowen (2012) identified 1) Cape Romano as the point separating the marine community composition of the Gulf of Mexico from that of the Caribbean province and 2) Cape Canaveral as separating the marine community composition of the Caribbean province from that of the Carolinian province. Cape Romano was in fact the approximate point of the genetic break for hogfish in the eastern Gulf of Mexico in our study (cluster 1 versus cluster 2; Fig. 1). Unfortunately, the large geographic gap in hogfish collections between Cape Canaveral and South Carolina made it impossible to identify the point of the genetic break between clusters 2 and 3 .

Strong genetic differences between the Gulf and Atlantic coasts of Florida are known for several estuarine and nearshore marine fishes, including common snook (Centropomus undecimalis) (Tringali and Bert, 1996), red drum (Sciaenops ocellatus) (Gold et al., 1999; Seyoum et al., 2000; Gold and Turner, 2002), and spotted seatrout (Cynoscion nebulosus) (Seyoum et al.5). Strong genetic and phenotypic differences between the Gulf and Atlantic coasts of Florida are recognized for the shelf-dwelling reef fish black sea bass (Centropristis striata) (Bowen and Avise, 1990; McCartney et al., 2013; McBride, 2014a). In contrast, only weak genetic differences have been found between the east and west coasts of Florida for other reef fishes, including red grouper (Epinephelus morio), scamp (Mycteroperca phenax) (Zatcoff et al., 2004), and vermilion snapper (Rhomboplites aurorubens) (Tringali and Higham, 2007). Similarly, there was little distinction between coasts for the pelagic king mackerel (Scomberomorus cavalla) (Gold et al., 2002). Curiously, at least in the southeastern United States, the stock structure of hogfish and black sea bass more closely resemble the stock structure of inshore and nearshore fishes (e.g., Seyoum et al. ${ }^{5}$ ) than that of offshore reef fishes or large coastal pelagic fishes (e.g., Zatcoff et al., 2004).

Hogfish reproduce in nearshore and offshore reef

\footnotetext{
5 Seyoum, S., M. D. Tringali, B. L. Barthel, V. Villanova, C. Puchulutegui, M. C. Davis, and A. C. C. Alvarez. 2014. Stock boundaries for spotted seatrout (Cynoscion nebulosus) in Florida based on population genetic structure. Technical Report TR-18, 27 p. [Available from Fish and Wildlife Research Institute, Florida Fish and Wildlife Conservation Commission, 100 Eighth Ave. SE, St. Petersburg, FL 337015020.]
}

habitats on the continental shelf (depths of 10-70 m; Colin, 1982; Collins and McBride, 2011). They are broadcast spawners who release buoyant eggs (Colin, 1982), facilitating pelagic dispersal of propagules from the harem arenas. Early larvae raised in laboratory tanks formed bubbles around themselves while floating near the surface (Colin, 1982), a behavior that may also contribute to dispersal. The planktonic larval phase has been estimated to last for approximately 35 days, preceding strong benthic orientation (Colin, 1982; Victor, 1986). Larvae are transported inshore, and juveniles settle in shallow, nearshore grass beds (Davis, 1976; Colin, 1982). Therefore, cross-shelf (offshore-inshore) dispersal of hogfish larvae is evident, but little is known about along-shelf dispersal.

Hydrodynamic flow around Florida is complex (Liu and Weisberg, 2005), and dispersal of hogfish throughout this region is likely influenced by larval behavior and mortality (Cowen et al., 2000; Leis, 2006; Huebert et al., 2010). Although these are poorly understood for this species, a qualitative assessment indicates that northward and southward larval dispersal is likely along the western Florida shelf in particular. The peak spawning period for hogfish in the eastern Gulf of Mexico (March-May; McBride et al., 2008; Collins and McBride, 2015) occurs at a time when the currents are shifting from a predominantly southeasterly flow to a northwesterly flow (Liu and Weisberg, 2005, 2012). Hogfish spawning, however, occurs to some extent in most months (all except September) (Collins and McBride, 2015). Spawning throughout the year would subject larvae to a diverse (and difficult to predict) set of conditions, both physical (e.g., temperature and seasonal shifts in currents) and biological (e.g., prey availability through seasonal plankton blooms), that may affect dispersal vectors and survival rates (Cowen, 2002; Leis and McCormick, 2002).

The Loop Current in the Gulf of Mexico is an upstream portion of the Gulf Stream and affects different areas of the west Florida shelf to differing degrees throughout the year. Along the west Florida shelf, current flows are weakest near Cape Romano, and the low currents there may present a barrier to gene flow, as evident by the break between clusters 1 and 2 ; but current direction on the shelf also shifts seasonally from a southerly to northerly flow, and a strong looping current near the shelf break interacts periodically with local wind forces (He and Weisberg, 2003). The Loop Current presumably occurs beyond the range of hogfish spawning on the west Florida shelf (cluster 1; spawning occurs at $<70 \mathrm{~m}$; Collins and McBride, 2015), but the effects of this major current and its associated eddies are difficult to assess because many regional ichthyoplankton surveys report taxa only to the family level or collect too few hogfish larvae for analysis (Richards et al., 1993; Huebert et al., 2010).

Along the Atlantic side of the Florida Keys, the dominant current flow is to the east, fed by the Florida Current that flows through the Florida Strait and into the Gulf Stream. This current flow indicates that the 
majority of larvae produced south of the Everglades region would be transported into the Florida Keys or Atlantic Ocean and there would be very little larval transport north along the west Florida shelf. Models of regional hydrodynamics combined with the increased information available regarding hogfish distribution and spawning could simulate larval dispersal and settlement around Florida. Elsewhere, biological data are lacking; for example, courtship in hogfish has been observed off North Carolina (Parker, 2000), but the timing and extent of spawning in this region (cluster 3) have not been described.

Adult behavior may also play an important role in determining connectivity and population structure (Frisk et al., 2014). Hogfish are protogynous hermaphrodites (McBride and Johnson, 2007). Sex change does not occur until fish are at least $305 \mathrm{~mm}$ in total length (TL) (Davis 1976), and most fish remain female until they are at least $350 \mathrm{~mm}$ TL (McBride and Johnson, 2007; Collins and McBride, 2011). A single, dominant male will spawn daily with multiple females in harems of up to 15 individuals (Colin, 1982; McBride and Johnson, 2007; Muñoz et al., 2010; Collins and McBride, 2011). For hogfish, stable harems and a strong association with reef habitats promote relatively strong site fidelity to specific locations for months or even years (Colin, 1982; Lindholm et al., 2006; Muñoz et al., 2010). However, gradual ontogenetic movement offshore with growth is evident.

Juveniles settle in shallow, inshore habitats (Davis, 1976; Collins and McBride, 2011), and hogfish <2 years old have rarely been collected from habitats deeper than $30 \mathrm{~m}$ (similarly, it is rare to collect individuals $>8$ years old from nearshore habitats). For those reasons, it is assumed that hogfish gradually move to deeper water farther from shore as they grow. Hogfish may live for 23 years (McBride and Richardson, 2007), and females mature as early as an age of 1-2 years (McBride and Johnson, 2007). Therefore, gradual movement of individuals across the shelf through time would increase the exposure of larvae to different environmental conditions and current regimes that may, as a result, affect larval distribution and gene flow. Finally, although there is no evidence of natal homing by hogfish, it has been documented for other reef fish (Paris et al., 2013) and should be considered a possibility.

Demographic differences in hogfish between or within regions of Florida have been noted (McBride and Richardson, 2007; McBride et al., 2008; Collins and McBride, 2011). In the central-eastern Gulf of Mexico, adult size, longevity, and fecundity differed between deepwater and shallow-water fish across the shelf (Collins and McBride, 2011; Collins and McBride, 2015), but these life history traits were unrelated to the genetic structure of hogfish (MERPDC, 2012). Similar demographic differences for hogfish have also been observed between the Gulf of Mexico and south Florida (Florida Keys) (McBride and Richardson, 2007; McBride et al., 2008). Although hogfish within these regions are now known to be genetically different, it seems unlikely that life history differences are solely the result of genetic differences. The effects of ontogenetic behaviors, as well as the effects of fishing on size at age, maturity, fecundity, and harem stability, likely play a significant role in the demographics of hogfish throughout the range of this species (McBride et al., 2008; Muñoz et al., 2010).

The close relationship between clusters 1 and 3 was surprising because both are geographically separated, and the genetic forces responsible for such a relationship are not readily apparent. The geographic isolation and modest sample size of cluster 3 may have led to a sample-specific association between clusters 1 and 3 , one that may not hold up once more samples from the Carolinas are examined and compared. Still, some specific genetic mechanisms could be operating and deserve consideration. Drift may be important within cluster 3 , which had the smallest $N_{\mathrm{e}}$, and thereby led to a coincidental similarity between clusters 1 and 3 . It is also possible that some environmental correlate along a latitudinal cline could be driving selection for particular genotypes, and the microsatellites, while neutral markers, could be linked in some way to adaptive markers. A possible driver for selection is temperature, which is high $\left(>25 \mathrm{C}^{\circ}\right)$ and relatively homogeneous around Florida during the summer (June-September), but, during the rest of the year, temperature is high only around south Florida (cluster 2) (He and Weisberg, 2003).

Drift and selection are possible, but the most testable hypothesis is based on gene flow. Suppose that hogfish in each cluster are disproportionally connected by hydrodynamically driven gene flow with a more southerly stock (McBride and Horodysky, 2004); in such a case, the most likely scenario is that cluster 2 alone is affected by introgression from the south, and the effect of such gene flow does not reach farther up along either the east or the west coast of Florida. The result would be as we report here: a disruption of the genetic continuity of hogfish around the Florida peninsula. Such a disruptive pattern has been reported for European anchovy (Engraulis encrasicolus), explained by introgression of an African population with populations around the Iberian peninsula (Zarraonaindia et al. 2012; Antoniou and Magoulas, 2014). This last hypothesis is particularly interesting because it would expand the currently understood sources of recruitment to the Florida Keys, but proving it would require examination of new collections from the Bahamas and Caribbean Sea.

Application of the findings in this study to monitoring, assessment, and regulatory actions regarding hogfish are relatively straight forward. Landings and fishing effort data in Florida are already collected at the county level (FWC ${ }^{1}$ ), and the Florida Keys are contained within one county (Monroe). Federal fisheries data can also be separated by coast (e.g., $\mathrm{NMFS}^{2}$ ), and it is likely that regional stock assessments will reveal further differences in fishing effort between regions.

Fishing effort within the region of cluster 1 is significant $\left(\mathrm{NMFS}^{2}\right)$, but pressure is less concentrated there 
than in cluster 2 because of the nature of the habitat and the expansiveness of the west Florida shelf. Fishing effort in cluster 2 is also high, but the effort is condensed into a much smaller area than that of cluster 1 and is highly accessible to divers throughout the year. In both clusters 1 and 2, hogfish in shallow waters are harvested from the population relatively soon after reaching legal size, particularly near areas of high human density (McBride and Richardson, 2007). Although commercial and recreational fisheries do exist within the region of cluster 3 , that area presumably has lower fishing pressure for hogfish because of the distance from shore required to reach hogfish habitat, as well as inclement weather patterns during the winter months and lower densities of humans in coastal areas.

Previous stock assessments designed to quantify regional fishing effort and landings have been challenging $\left(\right.$ Kingsley $\left.{ }^{6}\right)$. As an alternative, Ault et al. (2005) promoted a size-based approach to addressing the data-poor nature of hogfish assessment, and Collins and McBride $(2011,2015)$ underscored the importance of considering spatial demographic structure. The genetic data presented herein strongly indicate that regional assessments are warranted for at least the eastern Gulf of Mexico and south Florida, and a separate assessment should be considered for the broad (but still undefined) region of habitat that stretches from northeast Florida to North Carolina.

\section{Acknowledgments}

We thank all the members of the Saint Petersburg Underwater Club (SPUC) for their involvement in this project, as well as J. Atack, B. Bateman, L. Borden, E. Burge, C. Collier, K. Fex, T. Grogan, J. Haag, J. Herrera, J. Shepard, A. Solana, M. Stokley and the contributing participants of the St. Pete Open, Spearboard Open, Key West Open, and Wrightsville Beach Spearfishing Tournaments. The Marine Fisheries-Independent and Marine Fisheries-Dependent Monitoring programs of the Fish and Wildlife Research Institute, Florida Fish and Wildlife Conservation Commission, also provided specimens. E. Schotsman went above and beyond to collect data in south Florida. We are grateful to W. Cooper, D. Richardson, and 3 anonymous reviewers for their insightful comments. The majority of the work described herein was funded by grant NA05NMF4540040 to the Florida Fish and Wildlife Conservation Commission from NOAA's Cooperative Research Program, as well as through the U.S. Department of the Interior, U.S. Fish and Wildlife Service, under the Federal Aid in Sport Fish Restoration Program, Grant F-69.

\footnotetext{
${ }^{6}$ Kingsley, M. C. S (ed.). 2004. The hogfish in Florida: assessment review and advisory report. Report prepared for the South Atlantic Fishery Management Council, the Gulf of Mexico Fishery Management Council, and the National Marine Fisheries Service. Southeast Data, Assessment, and Review, Charleston, SC. [Available at website.]
}

\section{Literature cited}

Antoniou, A., and A. Magoulas.

2014. Application of mitochondrial DNA in stock identification. In Stock identification methods: applications in fishery science, $2^{\text {nd }}$ ed. (S. X. Cadrin, L. A. Kerr, and S. Mariani, eds.), p. 257-295. Academic Press, London. Article

Ault, J. S., S. G. Smith, and J. A. Bohnsack.

2005. Evaluation of average length as an estimator of exploitation status for the Florida coral-reef fish community. ICES J. Mar. Sci. 62:417-423. Article

Belkhir, K, P. Borsa, L. Chikhi, N. Raufaste, and F. Bonhomme. 2000. GENETIX 4.05, logiciel sous Windows ${ }^{\mathrm{TM}}$ pour la génétique des populations. Laboratoire Génome, Populations, Interactions CNRS UMR 5000, Université de Montpellier II, Montpellier, France.

Bowen, B. W., and J. C. Avise.

1990. Genetic structure of Atlantic and Gulf of Mexico populations of sea bass, menhaden, and sturgeon: influence of zoogeographic factors and life-history patterns. Mar. Biol. 107:371-381. Article

Briggs, J. C., and B. W. Bowen.

2012. A realignment of marine biogeographic provinces with particular reference to fish distributions. J. Biogeogr. 39:12-30. Article

Cadrin, S. X., L. A. Kerr, and S. Mariani.

2014. Stock identification methods, $2^{\text {nd }}$ ed., 566 p. Academic Press, San Diego, CA.

Claro, R., A. Garcia-Cagide, and R. Fernández de Alaiza.

1989. Caracteristicas biológicas del pez perro, Lachnolaimus maximus (Walbaum), en el golfo de Batabanó, Cuba. Rev. Invest. Mar. 10:239-252.

Colin, P. L.

1982. Spawning and larval development of the hogfish, Lachnolaimus maximus (Pisces: Labridae). Fish. Bull. 80:853-862.

Collins, A. B., and R. S. McBride.

2011. Demographics by depth: spatially explicit life-history dynamics of a protogynous reef fish. Fish. Bull. 109:232-242.

2015. Variations in reproductive potential between nearshore and offshore spawning contingents of hogfish in the eastern Gulf of Mexico. Fish. Manage. Ecol. 22:113-124. Article

Cowen, R. K., K. M. M. Lwiza, S. Sponaugle, C. B. Paris, and D. B. Olson.

2000. Connectivity of marine populations: Open or closed? Science 287:857-859. Article

Cowen, R. K.

2002. Larval dispersal and retention and consequences for population connectivity. In Coral reef fishes: dynamics and diversity in a complex ecosystem (P. F. Sale, ed.), p. 149-170. Academic Press, Amsterdam.

Davis, J. C.

1976. Biology of the hogfish, Lachnolaimus maximus (Walbaum), in the Florida Keys. M.S. thesis, 86 p. Univ. Miami, Coral Gables, FL.

Do, C., R. S. Waples, G. M. Macbeth, B. J. Tillet, and J. R. Ovenden.

2014. NeEstimator v2: re-implementation of software for the estimation of contemporary effective population size $\left(N_{\mathrm{e}}\right)$ from genetic data. Mol. Ecol. Resour. 14:209-214. Article 
Earl, D. A., and B. M. vonHoldt.

2012. STRUCTURE HARVESTER: a website and program for visualizing STRUCTURE output and implementing the Evanno method. Conserv. Genet. Resour. 4:359-361. Article

Evanno, G., S. Regnaut, and J. Goudet.

2005. Detecting the number of clusters of individuals using the software STRUCTURE: a simulation study. Mol. Ecol. 14:2611-2620. Article

Excoffier, L., and H. E. L. Lischer.

2010. Arlequin suite vers 3.5: a new series of programs to perform population genetics analyses under Linux and Windows. Mol. Ecol. Resour. 10:564-567. Article

Excoffier, L., P. E. Smouse, and J. M. Quattro.

1992. Analysis of molecular variance inferred from metric distances among DNA haplotypes: application to human mitochondrial DNA restriction data. Genetics 131:479-491.

Frisk, M. G., A. Jordaan, and T. J. Miller.

2014. Moving beyond the current paradigm in marine population connectivity: Are adults the missing link? Fish Fish. 15:242-254. Article

Gold, J. R., E. Pak, and D. A. DeVries.

2002. Population structure of king mackerel (Scomberomorus cavalla) around peninsular Florida, as revealed by microsatellite DNA. Fish. Bull. 100:491-509.

Gold, J. R., L. R. Richardson, and T. F. Turner.

1999. Temporal stability and spatial divergence of mitochondrial DNA haplotype frequencies in red drum (Sciaenops ocellatus) from coastal regions of the western Atlantic Ocean and Gulf of Mexico. Mar. Biol. 133:593-602. Article

Gold, J. R., and T. Turner.

2002. Population structure of red drum (Sciaenops ocellatus) in the northern Gulf of Mexico, as inferred from variation in nuclear-encoded microsatellites. Mar. Biol. 140:249-265. Article

Goudet, J.

2001. FSTAT, a program to estimate and test gene diversities and fixation indices (vers. 2.9.3.2). [Available at website.]

Guo, S. W., and E. A. Thompson.

1992. Performing exact test of Hardy-Weinberg proportions for multiple alleles. Biometrics 48:361-372. Article

He, R. Y., and R. H. Weisberg.

2003. A loop current intrusion case study on the west Florida shelf. J. Phys. Oceanogr. 33:465-477. Article

Hedrick, P. W.

1999. Perspective: highly variable loci and their interpretation in evolution and conservation. Evolution 53:313-318. Article

Hill, W. G.

1981. Estimation of effective population size from data on linkage disequilibrium. Genet. Res. 38:209-216. Article

Huebert, K. B., S. Sponaugle, and R. K. Cowen.

2010. Predicting the vertical distributions of reef fish larvae in the Straits of Florida from environmental factors. Can. J. Fish. Aquat. Sci. 67:1755-1767. Article

Jakobsson, M., and N. A. Rosenberg.

2007. CLUMPP: a cluster matching and permutation program for dealing with label switching and multimodality in analysis of population structure. Bioinformatics 23:1801-1806. Article
Kalinowski, S. T.

2002. How many alleles per locus should be used to estimate genetic distances? Heredity 88:62-65. Article

2005. Do polymorphic loci require large sample sizes to estimate genetic distances? Heredity 94:33-36. Article

Latter, B. D. H.

1972. Selection in finite populations with multiple alleles. III. Genetic divergence with centripetal selection and mutation. Genetics 70:475-490.

Leis, J. M.

2006. Are larvae of demersal fishes plankton or nekton? Adv. Mar. Biol. 51:57-141. Article

Leis, J. M., J. E. Caselle, I. R. Bradbury, T. Kristiansen, J. K. Llopiz, M. J. Miller, M. I. O'Connor, C. B. Paris, A. L. Shanks, S. M. Sogard, S. E. Swearer, E. A. Treml, R. D. Vetter, and R. R. Warner.

2013. Does fish larval dispersal differ between high and low latitudes? Proc. R. Soc., B 280:20130327. Article

Leis, J. M., and M. I. McCormick.

2002. The biology, behavior, and ecology of the pelagic, larval stage of coral reef fishes. In Coral reef fishes: dynamics and diversity in a complex ecosystem (P. F. Sale, ed.), p. 171-199. Academic Press, Amsterdam.

Lindholm, J., A. Knight, L. Kaufman, and S. Miller

2006. A pilot study of hogfish (Lachnolaimus maximus Walbaum 1792) movement in the Conch Reef Research Only Area (northern Florida Keys). NOAA Mar. Sanctuaries Conserv. Ser. NMSP-06-06, 14 p.

Lischer H. E. L., and L. Excoffier.

2012. PGDSpider: an automated data conversion tool for connecting population genetics and genomics programs. Bioinformatics 28:298-299. Article

Liu, Y., and R. H. Weisberg.

2005. Patterns of ocean current variability on the west Florida shelf using the self-organizing map. J. Geophys. Res. 110:C06003. Article

2012. Seasonal variability on the west Florida shelf. Prog. Oceanogr. 104:80-98. Article

Mariani, S., and D. Bekkevold.

2014. The nuclear genome: netural and adaptive markers in fisheries science. In Stock identification methods, $2^{\text {nd }}$ ed. (S. X. Cadrin, L. A. Kerr, and S. Mariani, eds.), p. 297-327. Academic Press, San Diego. Article

Malécot, G.

1955. Decrease of relationship with distance. Cold Spring Harbor Symp. Quant. Biol. 20:52-53.

McBride, R. S.

2014a. Managing a marine stock portfolio: stock identification, structure, and management of 25 fishery species along the Atlantic coast of the United States. N. Am. J. Fish. Manage. 34:710-734. Article

2014b. The continuing role of life history parameters to identify stock structure. In Stock identification methods, $2^{\text {nd }}$ ed. (S. X. Cadrin, L. A. Kerr, and S. Mariani, eds.), p. 77-107. Academic Press, San Diego, CA. Article

McBride, R. S., and A. Z. Horodysky.

2004. Mechanisms maintaining sympatric distributions of two ladyfish (Elopidae: Elops) morphs in the Gulf of Mexico and western North Atlantic Ocean. Limnol. Oceanogr. 49:1173-1181. [Available at website.]

McBride, R. S., and M. R. Johnson.

2007. Sexual development and reproductive seasonality of hogfish (Labridae: Lachnolaimus maximus), an hermaphroditic reef fish. J. Fish Biol. 71:1270-1292. Article 
McBride, R. S., and M. D. Murphy.

2003. Current and potential yield per recruit of hogfish, Lachnolaimus maximus, in Florida. Proc. Gulf Caribb. Fish. Inst. 54:513-525.

McBride, R. S., and A. K. Richardson.

2007. Evidence of size-selective fishing mortality from an age and growth study of hogfish (Labridae: Lachnolaimus maximus), a hermaphroditic reef fish. Bull. Mar. Sci. 80:401-417.

McBride, R. S., P. E. Thurman, and L. H. Bullock.

2008. Regional variations of hogfish (Lachnolaimus maximus) life history: consequences for spawning biomass and egg production models. J. Northwest Atl. Fish. Sci. 41:1-12.

McCartney, M. A., M. L. Burton, and T. G. Lima.

2013. Mitochondrial DNA differentiation between populations of black sea bass (Centropristis striata) across Cape Hatteras, North Carolina (USA). J. Biogeogr. 40:1368-1398. Article

MERPDC (Molecular Ecology Resources Primer Development Consortium), M. Andris, M. C. Arias, B. L. Barthel, B. H. Bluhm, J. Bried, D. Canal, X. M. Chen, P. Cheng, M. B. Chiappero, M. M. Coelho, A. B. Collins, M. Dash, M. C. Davis, M. Duarte, M.-P. Dubois, E. Françoso, M. A. Galmes, K. Gopal, P. Jarne, M. Kalbe, L. Karczmarksi, H. Kim, M. B. Martella, R. S. McBride, V. Negri, J. J. Negro, A. D. Newell, A. F. Piedade, C. Puchulutegui, L. Raggi, I. E. Samonte, J. H. Sarasola, D. R. See, S. Seyoum, M. C. Silva, C. Solaro, K. A. Tolley, M. D. Tringali, A. Vasemägi, L. S. Xu, and J. I. Zanón-Martínez.

2012. Permanent genetic resources added to Molecular Ecology Resources Database 1 February 2012-31 March 2012. Mol. Ecol. Resour. 12:779-781.

Muñoz, R. C., M. L. Burton, K. J. Brennan, and R. O. Parker.

2010. Reproduction, habitat utilization, and movements of hogfish (Lachnolaimus maximus) in the Florida Keys, U.S.A.: comparisons from fished versus unfished habitats. Bull. Mar. Sci. 86:93-116.

Nei, M.

1973. Analysis of gene diversity in subdivided populations. Proc. Natl. Acad. Sci. U.S.A. 70:3321-3323. Article 1987. Molecular evolutionary genetics, 513 p. Columbia Univ. Press, New York.

Nei, M. and A. K. Roychoudhury.

1974. Sampling variances of heterozygosity and genetic distance. Genetics 76:379-390.

Paris, C. B., J. Atema, J.-O. Irisson, M. Kingsford, G. Gerlach, and C. M. Guigand.

2013. Reef odor: a wake up call for navigation in reef fish larvae. PLoS ONE 8(8):e72808. Article

Park, S. D. E.

2001. Trypanotolerance in West African cattle and the population genetic effects of selection. Ph.D. diss, 241 p. Univ. Dublin, Dublin, Ireland.

Parker, R. O, Jr.

2000. Courtship in hogfish, Lachnolaimus maximus, and other behavior of reef fishes off Beaufort, North Carolina. J. Elisha Mitchell Sci. Soc. 116:260-261.

Peakall, R., and P. E. Smouse.

2006. GENALEX 6: genetic analysis in Excel. Population genetic software for teaching and research. Mol. Ecol. Notes 6:288-295. Article
2012. GenAlEx 6.5: genetic analysis in Excel. Population genetic software for teaching and research-an update. Bioinformatics 28:2537-2539. Article

Pritchard, J. K., M. Stephens, and P. Donnelly.

2000. Inference of population structure using multilocus genotype data. Genetics 155:945-959.

Pritchard, J. K., X. Wen, and D. Falush.

2009. Documentation for structure software: vers. 2.2. Univ. Chicago, Chicago, IL.

Raymond, M., and F. Rousset.

1995. An exact test for population differentiation. Evolution 49:1280-1283. [Available at website.]

Rice, W. R.

1989. Analyzing tables of statistical tests. Evolution 43:223-225. Article

Richards, W. J., M. F. McGowan, T. Leming, J. T. Lamkin, and S. Kelley.

1993. Larval fish assemblages at the loop current boundary in the Gulf of Mexico. Bull. Mar. Sci. 53:475-537.

Riginos, C., K. E. Douglas, Y. Jin, D. F. Shanahan, and E. A. Treml.

2011. Effects of geography and life history traits on genetic differentiation in benthic marine fishes. Ecography 34:566-575. Article

Robins, C. R., G. C. Ray, J. Douglass, and R. Freund.

1986. A field guide to Atlantic Coast fishes, 354 p. Houghton Mifflin Co., Boston.

Robinson, J. D., and G. R. Moyer.

2012. Linkage disequilibrium and effective population size when generations overlap. Evol.Appl.6:290-302. Article

Rousset, F.

2008. GENEPOP'007: a complete reimplementation of the GENEPOP software for Windows and Linux. Mol. Ecol. Resour. 8:103-106. Article

Seyoum, S., M. D. Tringali, T. M. Bert, D. McElroy, and R. Stokes.

2000. An analysis of genetic population structure in red drum, Sciaenops ocellatus, based on mtDNA control region sequences. Fish. Bull. 98:127-138.

Takezaki, N., M. Nei, and K. Tamura.

2010. POPTREE2: software for constructing population trees from allele frequency data and computing other population statistics with Windows-interface. Mol. Biol. Evol. 27:747-752. Article

Tringali, M. D., and T. M. Bert.

1996. The genetic stock structure of common snook (Centropomus undecimalis). Can. J. Fish. Aquat. Sci. 53:974-984. Article

Tringali, M. D., and M. Higham.

2007. Isolation-by-distance gene flow among vermilion snapper (Rhomboplites aurorubens Cuvier, 1892) from the Gulf of Mexico and southeastern United States. Gulf Mex. Sci. 2007:2-14.

Victor, B. C.

1986. Duration of the planktonic larval stage of one hundred species of Pacific and Atlantic wrasses (family Labridae). Mar. Biol. 90:317-326. Article

Waples, R. S.

2006. A bias correction for estimates of effective population size based on linkage disequilibrium at unlinked gene loci. Conserv. Genet. 7:167-184. Article

Weir, B. S., and C. C. Cockerham.

1984. Estimating F-statistics for the analysis of population structure. Evolution 38:1358-1370. Article 
Wilson, G. A., and B. Rannala.

2003. Bayesian inference of recent migration rates using multilocus genotypes. Genetics 163:1177-1191.

Wright, S.

1943. Isolation by distance. Genetics 28:114-138.

Zarraonaindia, I., M. Iriondo, A. Albaina, M. A. Pardo, C. Manzano, W. S. Grant, X. Irigoien, and A. Estonba.

2012. Multiple SNP markers reveal fine-scale popula- tion and deep phylogeographic structure in European anchovy (Engraulis encrasicolus L.). PLoS ONE 7(7):e42201. Article

Zatcoff, M. S., A. O. Ball, and G. R. Sedberry.

2004. Population genetic analysis of red grouper, Epinephelus morio, and scamp, Mycteroperca phenax, from the southeastern U.S. Atlantic and Gulf of Mexico. Mar. Biol. 144:769-777. Article 